ISSN 1907-9850

\title{
HIDROKSIAPATIT TERMODIFIKASI Fe DAN APLIKASINYA UNTUK ADSORPSI ZAT WARNA CONGO RED
}

\author{
Ni Komang Tria Paramita Septiari*, I Nengah Simpen dan Ni G. A. M. Dwi Adhi Suastuti \\ Program Studi Kimia FMIPA Universitas Udayana, Bukit Jimbaran, Badung, Bali 80361 \\ *Email: tria_paramita@yahoo.com
}

\begin{abstract}
ABSTRAK
Penelitian ini tentang adsorpsi zat warna congo red oleh hidroksiapatit hasil dekomposisi termal $400^{\circ} \mathrm{C}$ $\left(\mathrm{TA}_{1}\right)$ dan hidroksiapatit hasil dekomposisi termal $400^{\circ} \mathrm{C}$ termodifikasi $\mathrm{Fe}\left(\mathrm{TA}_{2}\right)$. Penelitian ini meliputi ekstraksi hidroksiapatit dari tulang secara dekomposisi termal, penentuan jumlah situs aktif hidroksiapatit secara titrasi asam basa, luas permukaan secara metode sorpsi biru metilen, perbandingan unsur $\mathrm{Ca} / \mathrm{P}$ dianalisis menggunakan laser induced breakdown spectroscopy(LIBS), kristalinitas secara difraksi sinar-X (XRD), penentuan waktu setimbang adsorpsi congo red, isoterm adsorpsi dan kapasitas adsorpsi congo red tanpa dan dengan penambahan $\mathrm{H}_{2} \mathrm{O}_{2}$ menggunakan spektrofotometer UV-Vis. Hasil penelitian menunjukkan bahwa jumlah situs aktif hidroksiapatit tertinggi ditunjukkan oleh $\mathrm{TA}_{1}$ yaitu $19,3493 \times 10^{23}$ situs/gram dan luas permukaan tertinggi ditunjukkan oleh $\mathrm{TA}_{1}$ yaitu $26,5375 \mathrm{~m}^{2} / \mathrm{g}$. Perbandingan unsur $\mathrm{Ca} / \mathrm{P}$ yang dihasilkan oleh $\mathrm{TA}_{1}$ yaitu 1,6425 sesuai literatur $(1,67)$. $\mathrm{TA}_{2}$ menghasilkan puncak XRD yang lebih mendekati puncak hidroksiapatit murni dengan intensitas 100 yang memiliki sudut $2 \theta 31,99^{\circ}$. Secara umum adsorpsi congo red tanpa dan dengan penambahan $\mathrm{H}_{2} \mathrm{O}_{2}$ terjadi peningkatan kapasitas teradsorpsi seiring dengan bertambahnya konsentrasi congo red dan lebih tinggi dibandingkan serbuk tulang kontrol $\left(\mathrm{T}_{0}\right)$.
\end{abstract}

Kata kunci: adsorpsi, congo red, dekomposisi termal, hidroksiapatit, $\mathrm{H}_{2} \mathrm{O}_{2}$

\begin{abstract}
This research paper discusses the adsorption of congo red by hydroxyapatite resulted from thermal decomposition at $400^{\circ} \mathrm{C}\left(\mathrm{TA}_{1}\right)$ and hydroxyapatite resulted from thermal decomposition at $400^{\circ} \mathrm{C}$ with $\mathrm{Fe}$ modification $\left(\mathrm{TA}_{2}\right)$. This studies involved the extraction of hydroxyapatite by thermal decomposition, determinations of the number of hydroxyapatite active sites by acid-base titration, surface area by the sorption of methylene blue, ratio of $\mathrm{Ca} / \mathrm{P}$ elements analized by laser induced breakdown spectroscopy(LIBS), crystallinity by Xray diffraction (XRD), determination of equilibrium adsorption time, adsorption isotherms and adsorption capacity of congo red with and without the addition of $\mathrm{H}_{2} \mathrm{O}_{2}$ analized by UV-Vis spectrophotometer. The results showed that the highest number of hydroxyapatiteactive sites and surface area of $\mathrm{TA}_{1}$ were $19.3493 \times 10^{23}$ sites/gram and 26.5375 $\mathrm{m}^{2} / \mathrm{g}$, respectively. The ratio of $\mathrm{Ca} / \mathrm{P}$ elements produced by $\mathrm{TA}_{1}$ was 1.6425 which was in accordance to the reference. The XRD peaksof $\mathrm{TA}_{2}$ was closer to the pure hydroxyapatite with an intensity 100 which had $2 \theta$ angle of $31.99^{\circ}$. Generally, the adsorption of congo red with and without the addition of $\mathrm{H}_{2} \mathrm{O}_{2}$ showed an increase in the amount adsorbed with the increase of the concentrations of congo red and this was higher than the control $\left(\mathrm{T}_{0}\right)$.
\end{abstract}

Keywords: adsorption, congo red, $\mathrm{H}_{2} \mathrm{O}_{2}$, hydroxyapatite, thermal decomposition

\section{PENDAHULUAN}

Tulang sapi merupakan salah satu bahan dasar yang digunakan untuk membuat kerajinan tangan di Bali. Pembuatan kerajinan tangan dengan bahan dasar tersebut, menghasilkan limbah tulang dan belum dimanfatkan,hanya dibuang begitu saja. Limbah tulang yang dihasilkan dari kerajinan tangan, tentunya dapat dimanfaatkan 
sebagai adsorben zat warna yang bernilai ekonomis.

Pemanfaatan tulang sapi sebagai adsorben dilakukan oleh Yusnita (2014), bahwa abu tulang sapi digunakan sebagai adsorben dengan penyerapan optimum terhadap ion nitrat berdasarkan pengaruh konsentrasi, dengan efisiensi penyerapan 80,05\%. Penelitian Syamberah (2014), menunjukkan bahwa arang tulang sapi dapat digunakan sebagai adsorben ion besi, tembaga, sulfat, dan sianida dengan penyerapan optimum secara berturut-turut 99,96; 99,64; 68,27; dan 69,59\%.

Peningkatan kemampuan adsorpsi dapat dilakukan dengan cara modifikasi menggunakan Fe. Penelitian Permana (2010), menunjukkan bahwa serbuk tulang sapi teraktivasi larutan $\mathrm{NaOH}$ dan termodifikasi $\mathrm{Fe}_{2} \mathrm{O}_{3}$ memiliki kemampuan adsorpsi yang baik dalam menyerap $\mathrm{Cr}$ (III) yaitu sebesar $12,49 \mathrm{mg} / \mathrm{g}$.

Pemanfaatan adsorben dari tulang sapi limbah juga dapat diaplikasikan untuk mengadsorpsi zat warna, karena zat warna kini telah banyak digunakan seperti pada industri tekstil, sehingga dapat menghasilkan dampak positif dan negatif. Dampak positif adalah memberikan kesan terbaik warna produk yang dihasilkan dari industri tekstil. Sedangkan, dampak negatifnya yaitu pembuangan limbah zat warna yang tidak terkontrol, dapat merusak lingkungan. Zat warna dari limbah cair industri tekstil merupakan senyawa organik yang memiliki struktur aromatic, sehingga sulit terdegradasi secara alamiah dan tidak ramah lingkungan (Sugiharto, 1987). Pemanfaatan hidroksiapatit sebagai adsorben zat warna dilakukan oleh Adel et al. (2015), yang menunjukkan bahwa sintesis hidroksiapatit yang dimodifikasi secara organik berpotensi untuk menyerap zat warna Malachite Green, dengan kapasitas adsorpsi 188,18 mg/g.

Berdasarkan uraian tersebut, penelitian tentang adsorpsi zat warna congo red menggunakan adsorben hidroksiapatit, yang diekstraksi secara termal dari tulang sapi limbah kerajinan termodifikasi Fe. Hidroksiapatit termodifikasi $\mathrm{Fe}$ ini diharapkan dapat meningkatkan kemampuan adsorpsi zat warna. Sebelum dilakukan adsorpsi terhadap zat warna congo red, tulang sapi tersebut diekstraksi dan dimodifikasi $\mathrm{Fe}$ kemudian dikarakterisasi menggunakan XRD untuk mengetahui kristalinitas hidroksiapatit. LIBS (Laser Induced Breakdown Spectroscopy) digunakan untuk mengetahui perbandingan unsur $\mathrm{Ca} / \mathrm{P}$ dan $\mathrm{Fe}$, metode adsorpsi biru metilen untuk mengetahui luas permukaan spesifik dan titrasi asam basa untuk mengetahui kebasaan dan situs aktif permukaan, serta menentukan kapasitas adsorpsi dari hidroksiapatit tanpa dan dengan penambahan $\mathrm{H}_{2} \mathrm{O}_{2}$ dalam adsorbat. Penambahan $\mathrm{H}_{2} \mathrm{O}_{2}$ dapat berfungsi untuk meningkatkan laju reaksi, sehingga dapat mengoptimalkan adsorpsi zat warna congo red (Patnaik, 2002).

\section{MATERI DAN METODE}

\section{Bahan}

Bahan yang digunakan dalam penelitian ini yaitu aseton, hidrogen peroksida $\left(\mathrm{H}_{2} \mathrm{O}_{2}\right)$, $\mathrm{NaOH}$, biru metilen, $\mathrm{KOH}, \mathrm{FeCl}_{3} \cdot 6 \mathrm{H}_{2} \mathrm{O}$, akuades, congo red dan serbuk tulang sapi yang diambil pada tanggal 30 Januari 2016 diDesa Tampaksiring, Gianyar, Bali.

\section{Peralatan}

Alat yang digunakan dalam penelitian ini yaitu oven, labu ukur, pipet volume, Erlenmeyer, mortar, ayakan 400 mesh, stirrer, timbangan analitik dan pencatat waktu.

\section{Cara Kerja \\ Preparasi Serbuk Tulang}

Serbuk tulang sapi dicuci menggunakan aseton dan akuades yang bertujuan untuk menghilangkan kandungan lemak serta kotoran yang menempel pada serbuk tulang, kemudian serbuk tulang dikeringkan dalam oven pada suhu $160^{\circ} \mathrm{C}$ selama 12 jam. Serbuk tulang sapi yang sudah kering diayak menggunakan ayakan 400 mesh, selanjutnya disimpan dalam desikator dan diberi kode $\mathrm{T}_{0}$.

\section{Ekstraksi Hidroksiapatit dari Serbuk Tulang}

Tiga ratus (300) gram serbuk tulang ditempatkan pada cawan porselen kemudian dikalsinasi pada suhu $400^{\circ} \mathrm{C}$ selama 6 jam. Setelah itu, hidroksiapatit diberi kode $\mathrm{TA}_{1}$ dan disimpan dalam desikator. 


\section{Modifikasi Hidroksiapatit dengan Fe}

Lima puluh (50) gram adsorben $\mathrm{TA}_{1}$ dicampur dengan $25 \mathrm{~mL}$ larutan $\mathrm{FeCl}_{3} 10 \%$ dan

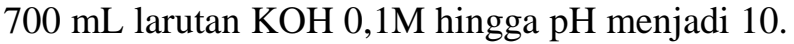
Campuran diinteraksikan dan suspensi didiamkan selama 20 hari pada suhu kamar. Setelah proses reaksi, suspensi disaring, dibilas dengan akuades dan dikeringkan dalam oven pada suhu $60^{\circ} \mathrm{C}$. Hidroksiapatit yang telah termodifikasi $\mathrm{Fe}$ disimpan dalam desikator dan diberi kode $\mathrm{TA}_{2}$.

\section{Penentuan Waktu Setimbang, Isoterm, dan} Kapasitas Adsorpsi

Sebanyak 0,10 gramhidroksiapatit $\left(\mathrm{T}_{0}\right.$, $\mathrm{TA}_{1}$ dan $\mathrm{TA}_{2}$ ) masing - masing ditambahkan 20 $\mathrm{mL}$ congo red $50 \mathrm{mg} / \mathrm{L}$. Campuran diaduk dengan pengaduk magnet dengan waktu interaksi 10, 15, 30, dan 60 menit. Selanjutnya, disaring dan filtratnya diukur dengan spektrofotometer UV-Vis. Absorbansi yang terbaca kemudian dimasukkan ke dalam persamaan regresi linier, sehingga konsentrasi congo red dalam filtrat dapat ditentukan. Untuk mengetahui waktu setimbang adsorpsi, dibuat grafik antara banyaknya congo redyang teradsorpsitiap gram adsorben terhadap waktu interaksi. Waktu setimbang ditentukan dari waktu interaksi minimal yang memberikan konsentrasicongo redteradsorpsi tertinggi.

Penentuan isoterm adsorpsi pada adsorben tanpa dan dengan penambahan $\mathrm{H}_{2} \mathrm{O}_{2}$ dilakukan pada masing-masing adsorben $\left(\mathrm{T}_{0}, \mathrm{TA}_{1}\right.$ dan $\left.\mathrm{TA}_{2}\right)$ menggunakan 4 variasi konsentrasi larutan congo red yaitu 40, 50, 60, dan $70 \mathrm{mg} / \mathrm{L}$, masing-masing sebanyak $25 \mathrm{~mL}$ dimasukkan ke dalam erlenmeyer. Sebanyak 0,10 gram masing-masing adsorben $\left(\mathrm{T}_{0}, \mathrm{TA}_{1}\right.$ dan $\left.\mathrm{TA}_{2}\right)$ dimasukkan ke dalam setiap Erlenmeyer, diinteraksikan selama waktu yang diperoleh dari penentuan waktu setimbang.
Kemudian, campuran disaring dan absorbansi filtrat diukur menggunakan Spektrofotometer UVVis.Cara yang sama dilakukan pula pada penambahan $\mathrm{H}_{2} \mathrm{O}_{2}$, dengan cara sebanyak $5,0 \mathrm{~mL}$ larutan $\mathrm{H}_{2} \mathrm{O}_{2}$ variasi konsentrasi 0,$5 ; 1,0 ; 1,5$; dan $2,0 \%$ ditambahkan pada larutan congo red dan diaduk hingga homogen kemudian ditambahkan dengan 0,10 gram adsorben.

\section{HASIL DAN PEMBAHASAN}

\section{Situs Aktif Permukaan}

Penentuan situs aktif permukaan dilakukan untuk mengetahui jumlah situs aktif yang terdapat pada hidroksiapatit. Jumlah asam dan basa hidroksiapatit merupakan jumlah situs aktif per satuan luas permukaan atau tiap gram hidroksiapatit tersebut. Situs aktif pada hidroksiapatit ditentukan secara tirasi asam basa. Adapun nilai keasaman, kebasaan, dan situs aktif permukaan hidroksiapatit terangkum dalam Tabel 1.

Tabel 1 menunjukkan bahwa hidroksiapatit hasil dekomposisi termal $400^{\circ} \mathrm{C}$ termodifikasi $\mathrm{Fe}\left(\mathrm{TA}_{2}\right)$ memiliki nilai kebasaan lebih tinggi dibandingkan serbuk tulang $\left(\mathrm{T}_{0}\right)$ dan hasil dekomposisi termal $400^{\circ} \mathrm{C}\left(\mathrm{TA}_{1}\right)$, namun situs aktif hidroksiapatit hasil dekomposisi termal $400^{\circ} \mathrm{C}$ termodifikasi $\mathrm{Fe}\left(\mathrm{TA}_{2}\right)$ lebih rendah dari hidroksiapatit hasil dekomposisi termal $400^{\circ} \mathrm{C}$ $\left(\mathrm{TA}_{1}\right)$. Adanya penurunan jumlah situs aktif diduga disebabkan oleh tertutupnya pori akibat modifikasi Fe,yang dibarengi dengan penutupan beberapa situs aktif yang terbentuk sebelum modifikasi dengan Fe.

Tabel 1. Nilai Keasaman, Kebasaan, dan Situs Aktif Permukaan Hidroksiapatit

\begin{tabular}{cccc}
\hline Adsorben & $\begin{array}{c}\text { Keasaman permukaan } \\
(\mathrm{mmol} / \mathrm{gram})\end{array}$ & $\begin{array}{c}\text { Kebasaan permukaan } \\
(\mathrm{mmol} / \mathrm{gram})\end{array}$ & $\begin{array}{c}\text { Jumlah situs aktif } \\
(\text { situs/gram })\end{array}$ \\
\hline $\mathrm{T}_{0}$ & $0,9012 \pm 5,24 \times 10^{-2}$ & $0,5721 \pm 5,1730 \times 10^{-2}$ & $8,8721 \times 10^{23}$ \\
$\mathrm{TA}_{1}$ & $0,9361 \pm 1,5122 \times 10^{-2}$ & $2,2770 \pm 5,9805 \times 10^{-2}$ & $19,3493 \times 10^{23}$ \\
$\mathrm{TA}_{2}$ & $0,8051 \pm 1,5126 \times 10^{-2}$ & $2,3268 \pm 4,5716 \times 10^{-2}$ & $18,8602 \times 10^{23}$
\end{tabular}

Keterangan : serbuk tulang $\left(\mathrm{T}_{0}\right)$, hidroksiapatit hasil dekomposisi termal $400^{\circ} \mathrm{C}\left(\mathrm{TA}_{1}\right)$, hidroksiapatit hasil dekomposisi termal $400^{\circ} \mathrm{C}$ termodifikasi $\mathrm{Fe}\left(\mathrm{TA}_{2}\right)$ 


\section{Luas Permukaan Hidroksiapatit}

Luas permukaan hidroksiapatit disajikan dalam Tabel 2.

Tabel 2. Luas permukaan Adsorben

\begin{tabular}{cc}
\hline Adsorben & $\mathrm{S}\left(\mathrm{m}^{2} / \mathrm{g}\right)$ \\
\hline $\mathrm{T}_{0}$ & 26,2166 \\
$\mathrm{TA}_{1}$ & 26,5375 \\
$\mathrm{TA}_{2}$ & 23,9949 \\
\hline
\end{tabular}

Keterangan : serbuk tulang $\left(\mathrm{T}_{0}\right)$, hidroksiapatit hasil dekomposisi termal $400^{\circ} \mathrm{C}$ $\left(\mathrm{TA}_{1}\right)$, hidroksiapatit hasil dekomposisi termal $400^{\circ} \mathrm{C}$ termodifikasi $\mathrm{Fe}$ $\left(\mathrm{TA}_{2}\right)$

Tabel 2 menunjukkan bahwa luas permukaan hidroksiapatit yang dimiliki oleh hidroksiapatit hasil dekomposisi termal $400^{\circ} \mathrm{C}\left(\mathrm{TA}_{1}\right)$ dan serbuk tulang $\left(\mathrm{T}_{0}\right)$ lebih tinggi dari hidroksiapatit hasil dekomposisi termal termodifikasi $\mathrm{Fe}\left(\mathrm{TA}_{2}\right)$. Hal ini disebabkan oleh telah terjadinya penutupan pori akibat termodifikasi Fe, sehingga biru metilen yang tersorpsi oleh hidroksiapatit hasil dekomposisi termal $400^{\circ} \mathrm{C}$ termodifikasi $\mathrm{Fe}\left(\mathrm{TA}_{2}\right)$ lebih kecil daripada hidroksiapatit hasil dekomposisi termal $400^{\circ} \mathrm{C}\left(\mathrm{TA}_{1}\right)$ dan serbuk tulang $\left(\mathrm{T}_{0}\right)$.

\section{Perbandingan $\mathrm{Ca} / \mathrm{P}$ dan Kelimpahan $\mathrm{Fe}$}

Laser Induced Breakdown Spectroscopy (LIBS) digunakan untuk mengetahui kelimpahan atom dalam hidroksiapatit, sehingga perbandingan atom dapat diketahui. Perbandingan yang diidentifikasi dari hidroksiapatit adalah perbandingan unsur $\mathrm{Ca}$ dan $\mathrm{P}$ dan kelimpahan unsur $\mathrm{Fe}$.

Tabel 3. Perbandingan unsur $\mathrm{Ca} / \mathrm{P}$ dan kelimpahan $\mathrm{Fe}$

\begin{tabular}{ccc}
\hline Adsorben & $\mathrm{Fe}$ (a.u.) & $\mathrm{Ca} / \mathrm{P}$ (a.u.) \\
\hline $\mathrm{T}_{0}$ & 206 & 1,1598 \\
$\mathrm{TA}_{1}$ & 194 & 1,6425 \\
$\mathrm{TA}_{2}$ & 311 & 1,4913 \\
\hline
\end{tabular}

Keterangan : Serbuk tulang $\left(\mathrm{T}_{0}\right)$, hidroksiapatit hasil dekomposisi termal $400^{\circ} \mathrm{C}$ $\left(\mathrm{TA}_{1}\right)$, hidroksiapatit hasil dekomposisi termal $400^{\circ} \mathrm{C}$ termodifikasi $\mathrm{Fe}$ $\left(\mathrm{TA}_{2}\right)$
Tabel 3 diperoleh bahwa perbandingan $\mathrm{Ca} / \mathrm{P}$ terendah pada serbuk tulang $\left(\mathrm{T}_{0}\right)$, sementara terbesar pada hidroksiapatit hasil dekomposisi termal $400^{\circ} \mathrm{C}\left(\mathrm{TA}_{1}\right)$ yaitu 1,6425 sesuai dengan hasil perbandingan $\mathrm{Ca} / \mathrm{P}$ hidroksiapatit penelitian Parahita (2016) dan mendekati nilai perbandingan $\mathrm{Ca} / \mathrm{P}$ sesuai literatur yaitu 1,67 (Ooi, et al., 2007). Kandungan Fe mengalami peningkatan dari serbuk tulang $\left(\mathrm{T}_{0}\right)$, hidroksiapatit hasil dekomposisi termal $400^{\circ} \mathrm{C} \quad\left(\mathrm{TA}_{1}\right)$ dan hidroksiapatit hasil dekomposisi termal $400^{\circ} \mathrm{C}$ termodifikasi $\mathrm{Fe}\left(\mathrm{TA}_{2}\right)$ sesuai dengan hasil perbandingan $\mathrm{Ca} / \mathrm{P}$ menurun menjadi 1,4913. Ini berarti, telah terjadi substitusi antara $\mathrm{Fe}$ dengan $\mathrm{Ca}$ atau $\mathrm{Fe}$ telah masuk ke dalam struktur hidroksiapatit.

\section{Kristanilitas Hidroksiapatit}

Karakterisasi hidroksiapatit dengan XRD digunakan untuk mengetahui fasa kristalinitas hidroksiapatit. Ini dilakukan dengan cara membandingkan data intensitas puncak-puncak difraktogram yang diperoleh dengan database XRD JCPDS No. 9-432, yang menunjukkan pola XRD dari hidroksiapatit. Pola XRD serbuk tulang $\left(\mathrm{T}_{0}\right)$ ditampilkan pada Gambar 1.

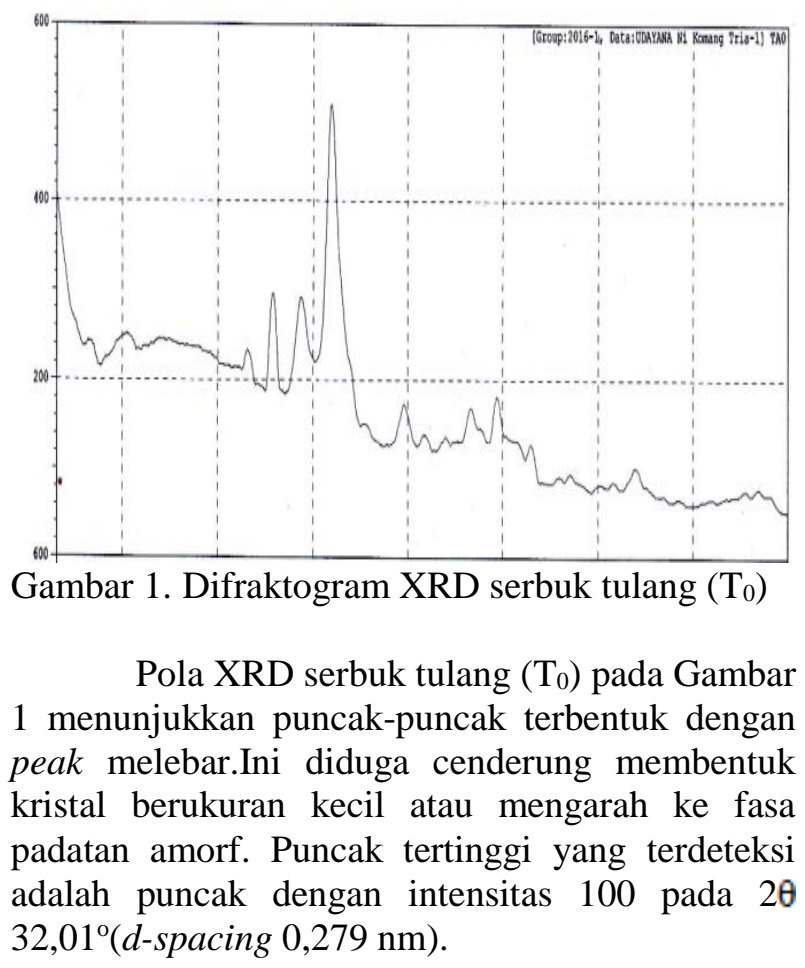


Pola XRD hidroksiapatit hasil dekomposisi termal $400^{\circ} \mathrm{C}\left(\mathrm{TA}_{1}\right)$ pada Gambar 2, memiliki puncak tertinggi yang terdeteksi adalah puncak dengan intensitas 100 pada $2 \theta 32,00^{\circ}$ atau $d$ spacing $0,279 \mathrm{~nm}$.

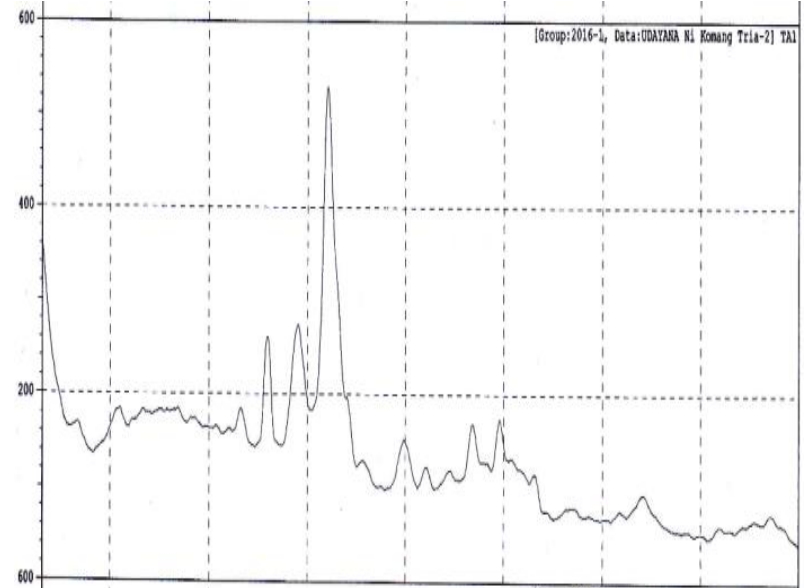

Gambar 2. Difraktogram XRD hidroksiapatit hasil dekomposisi termal $400^{\circ} \mathrm{C}\left(\mathrm{TA}_{1}\right)$

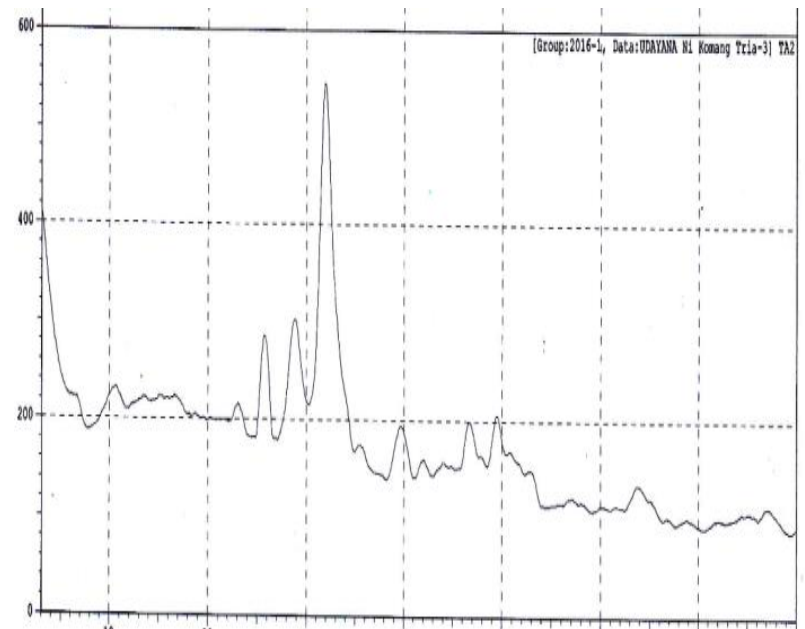

Gambar 3. Difraktogram XRD hidroksiapatit hasil dekomposisi termal $400^{\circ} \mathrm{C}$ termodifikasi $\mathrm{Fe}\left(\mathrm{TA}_{2}\right)$

Pola XRD hidroksiapatit hasil dekomposisi termal $400^{\circ} \mathrm{C}$ termodifikasi $\mathrm{Fe} \quad\left(\mathrm{TA}_{2}\right)$ (Gambar 3) memiliki puncak tertinggi yang terdeteksi adalah puncak dengan intensitas 100 pada $2 \theta 31,99^{\circ}$ atau $d$-spacing $0,279 \mathrm{~nm}$. Dari ketiga jenis adsorben, puncak yang dihasilkan oleh hidroksiapatit hasil dekomposisi termal termodifikasi $\mathrm{Fe}\left(\mathrm{TA}_{2}\right)$ tersebut lebih mendekati dengan database JCPDS No. 9-432, daripada puncak yang dihasilkan oleh serbuk tulang $\left(\mathrm{T}_{0}\right)$ dan hidroksiapatit hasil dekomposisi termal $400^{\circ} \mathrm{C} \quad\left(\mathrm{TA}_{1}\right)$. Puncak tertinggi hidroksiapatit murni dengan intensitas 100 memiliki pada $2 \theta 31,77^{\circ}$ atau $d$ spacing $0,281 \mathrm{~nm}$. Puncak lain yang tidak sesuai dengan database diduga karena masih adanya kontaminan pada hidroksiapatit. Adanya modifikasi dengan $\mathrm{Fe}$ dapat meningkatkan intensitas yang dihasilkan dan puncak yang dihasilkan lebih mendekati puncak tertinggi hidroksiapatit murni (Park et al, 2012). Adanya modifikasi dengan $\mathrm{Fe}$ dalam hidroksiapatit dapat menyebabkan tergantikannya ion Ca pada struktur hidroksiapatit oleh kation $\mathrm{Fe}^{2+}$, sehingga mengakibatkan pergeseran difraksi $\mathrm{Fe}$ pengganti Ca dalam struktur tersebut.

Waktu Setimbang, Isoterm, dan Kapasitas Adsorpsi tanpa dan dengan Penambahan $\mathrm{H}_{2} \mathrm{O}_{2}$

Penentuan waktu setimbang adsorpsi bertujuan untuk mengetahui waktu minimum yang dibutuhkan oleh adsorben dalam mengadsorpsi zat warna congo red secara maksimum hingga mencapai keadaan setimbang (jenuh).

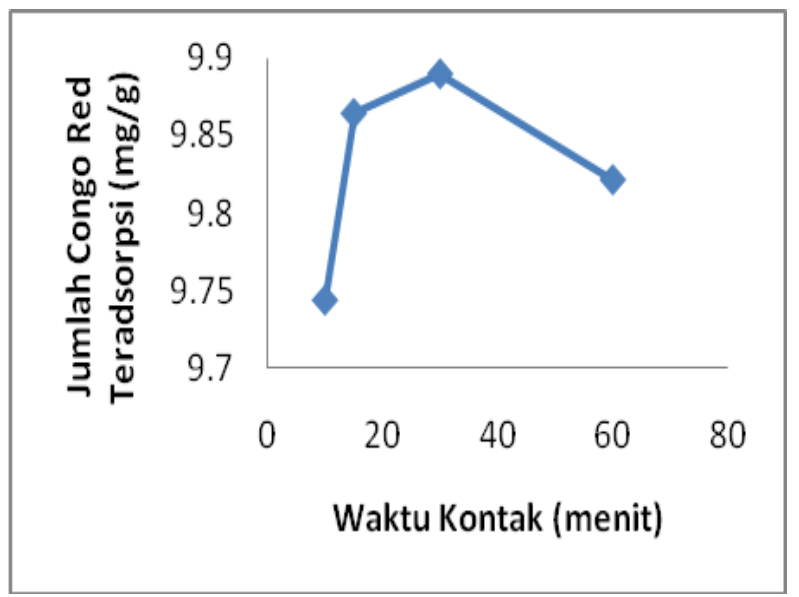

Gambar 4. Waktu kontak optimum dari adsorben

Berdasarkan pada Gambar 4 apat dilihat bahwa jumlah congo red yang teradsorpsi meningkat sampai waktu kontak 30 menit, kemudian mengalami penuruan setelah diinteraksikan selama 60 menit. Hal ini menunjukkan bahwa waktu kontak 30 menit merupakan 
waktu kontak optimum adsorpsi dengan penyerapan congo red tertinggi $9,8901 \mathrm{mg} / \mathrm{g}$.

Pengaruh variasi konsentrasi congo red awal tanpa dan dengan penambahan $\mathrm{H}_{2} \mathrm{O}_{2}$ terhadap jumlah yang teradsorpsi $\left(Q_{a d s}\right)$ disajikan dalam grafik pada Gambar 5-9.

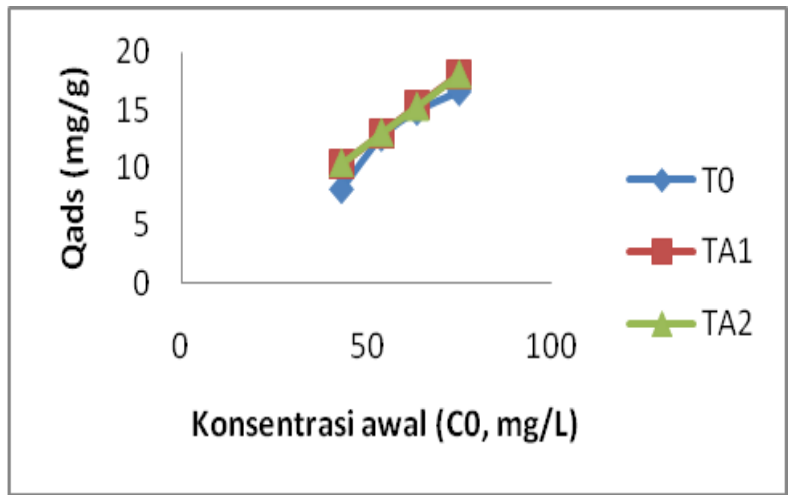

Gambar 5. Grafik variasi konsentrasi congo redawal terhadap jumlah yang teradsorpsi tanpa penambahan $\mathrm{H}_{2} \mathrm{O}_{2}$

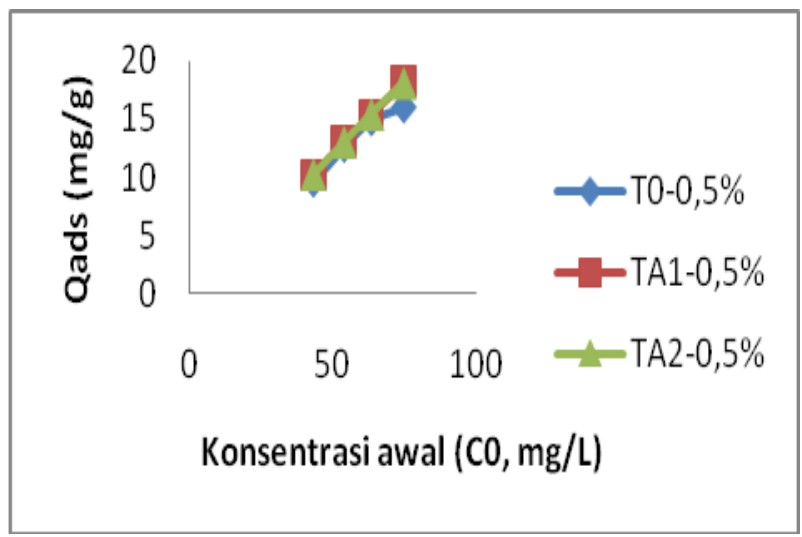

Gambar 6. Grafik variasi konsentrasi congo redawal terhadap jumlah yang teradsorpsi pada penambahan $\mathrm{H}_{2} \mathrm{O}_{2}$ $0,5 \%$

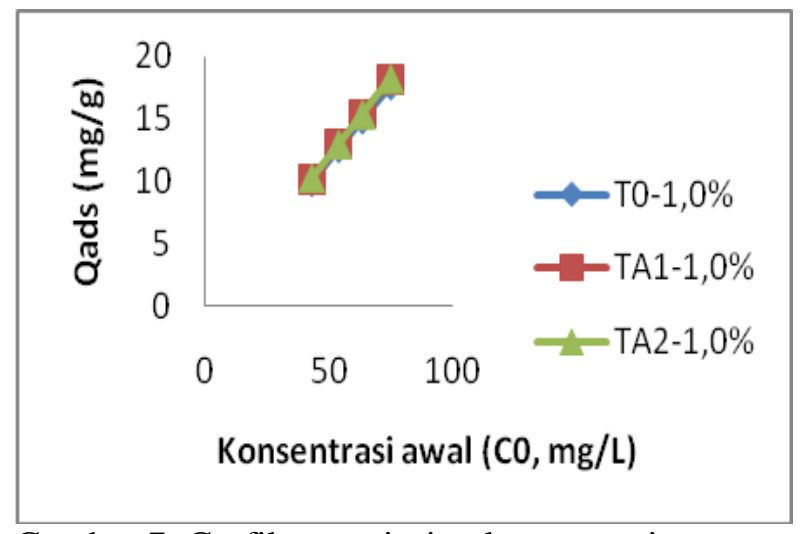

Gambar 7. Grafik variasi konsentrasi congo redawal terhadap jumlah yang teradsorpsi pada penambahan $\mathrm{H}_{2} \mathrm{O}_{2}$ $1,0 \%$

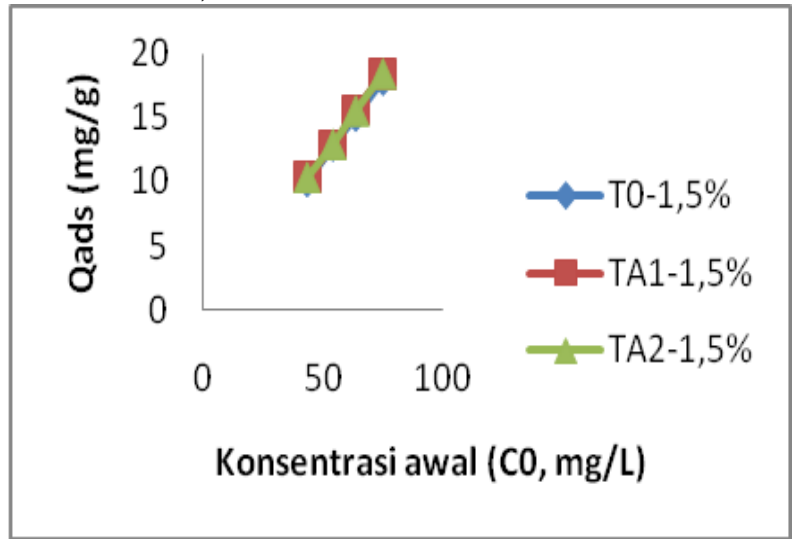

Gambar 8. Grafik variasi konsentrasi congo redawal terhadap jumlah yang teradsorpsi pada penambahan $\mathrm{H}_{2} \mathrm{O}_{2}$ $1,5 \%$

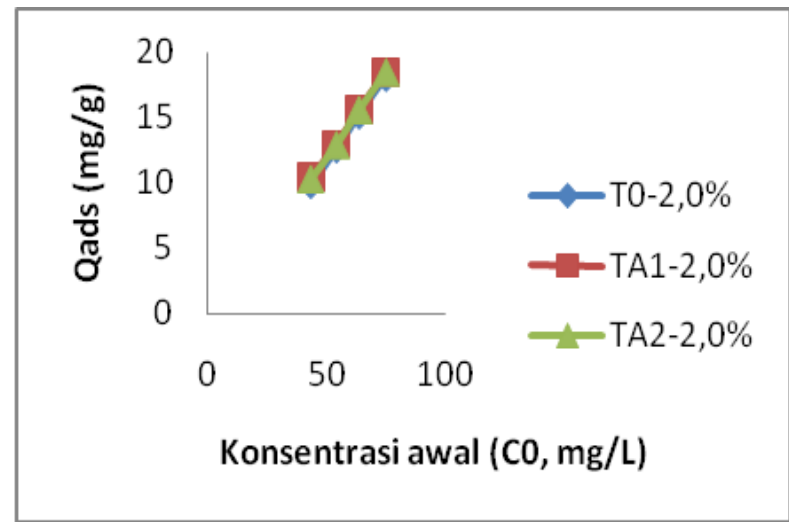

Gambar 9. Grafik variasi konsentrasi congo redawal terhadap jumlah yang teradsorpsi pada penambahan $\mathrm{H}_{2} \mathrm{O}_{2}$ $2,0 \%$ 
Grafik pada Gambar 5, 6, 7, 8, dan 9 menunjukkan bahwa secara umum adsorpsi congo red tanpa dan dengan penambahan $\mathrm{H}_{2} \mathrm{O}_{2}$ mengalami peningkatan jumlah yang teradsorpsi seiring dengan bertambahnya konsentrasi congo red. Hal ini berarti, peningkatan konsentrasi awal berpengaruh terhadap peningkatan kemampuan adsorpsi congo red. Jumlah congo red yang teradsorpsi secara umum relatif lebih tinggi pada adsorben $\mathrm{TA}_{1}$ dan $\mathrm{TA}_{2}$ dibandingkan $\mathrm{T}_{0}$. Penambahan konsentrasi $\mathrm{H}_{2} \mathrm{O}_{2}$ juga menyebabkan peningkatan jumlah konsentrasi congo red yang teradsorpsi.

Isoterm adsorpsi memiliki tipe-tipe berdasarkan klasifikasi Gilles yang dapat diketahui melalui grafik pengaruh antara konsentrasi kesetimbangan terhadap jumlah yang teradsorpsi $\left(Q_{a d s}\right)$ tanpa dan dengan penambahan $\mathrm{H}_{2} \mathrm{O}_{2}$ seperti pada gambar berikut.

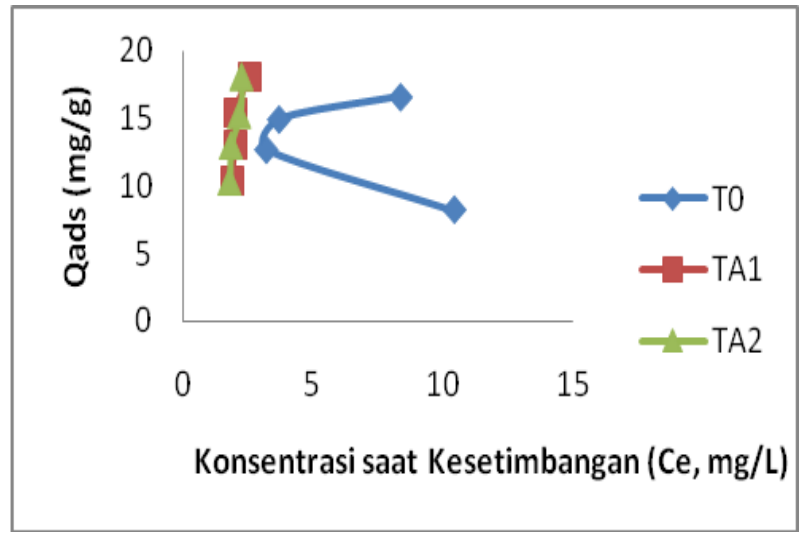

Gambar 10. Grafik model adsorpsi congo redtanpa penambahan $\mathrm{H}_{2} \mathrm{O}_{2}$

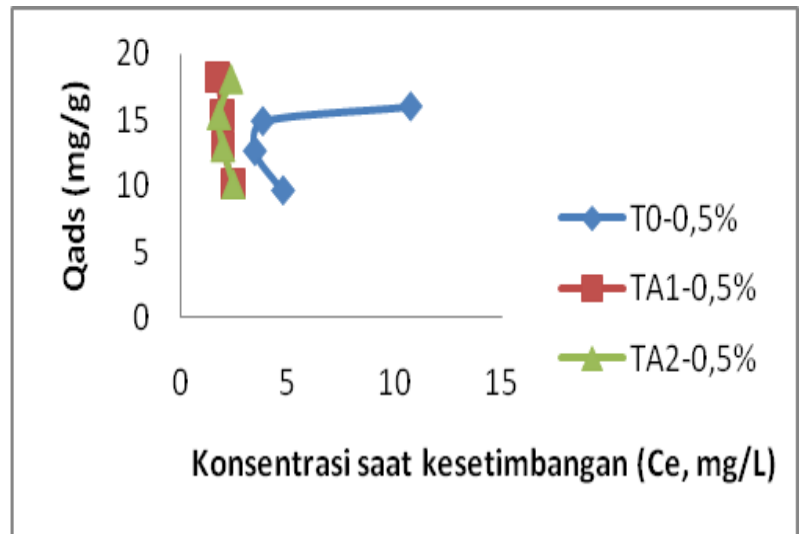

Gambar 11. Grafik model adsorpsi congo redpada penambahan $\mathrm{H}_{2} \mathrm{O}_{2} 0,5 \%$

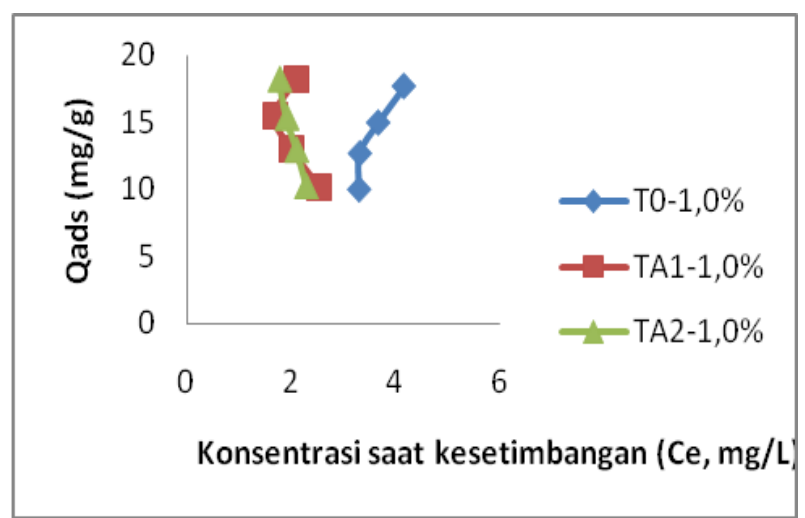

Gambar 12. Grafik model adsorpsi congo redpada penambahan $\mathrm{H}_{2} \mathrm{O}_{2}$ 1,0\%

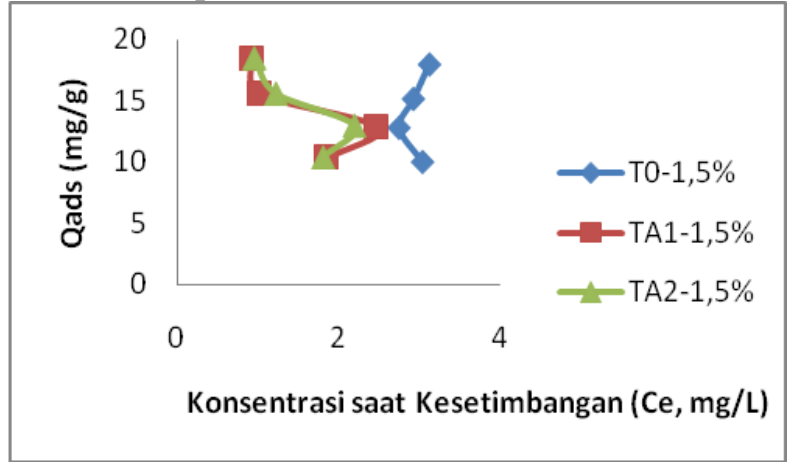

Gambar 13. Grafik model isoterm adsorpsicongo redpada penambahan $\mathrm{H}_{2} \mathrm{O}_{2}$ 1,5\%

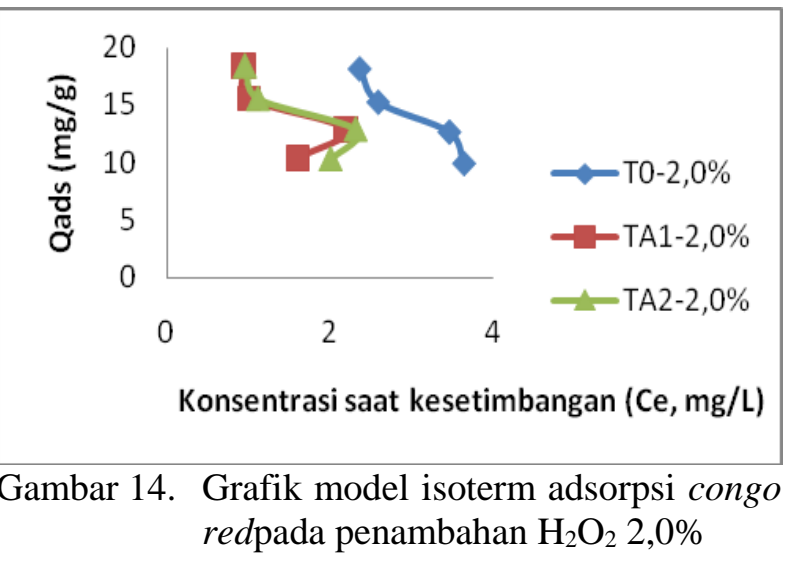

Berdasarkan grafik pada Gambar 10,11,12, 13, dan 14, serbuk tulang $\left(\mathrm{T}_{0}\right)$, serbuk tulang $\left(\mathrm{T}_{0}\right)$ dengan penambahan $\mathrm{H}_{2} \mathrm{O}_{2} 0,5 ; 1,0$; dan 1,5\%, hidroksiapatit hasil dekomposisi termal $400^{\circ} \mathrm{C}$ $\left(\mathrm{TA}_{1}\right)$ dengan penambahan $\mathrm{H}_{2} \mathrm{O}_{2} \quad 1,0 \%$ dan hidroksiapatit hasil dekomposisi termal $400^{\circ} \mathrm{C}$ termodifikasi $\mathrm{Fe}\left(\mathrm{TA}_{2}\right)$ dengan penambahan $\mathrm{H}_{2} \mathrm{O}_{2}$ 
0,5\% mengikuti isoterm adsorpsi tipe- $\mathrm{L}$ yang dikenal dengan isoterm adsorpsi Langmuir. Tipe ini mengindikasikan adanya afinitas yang relatif tinggi antara adsorben dengan zat terlarut pada tahap awal. Sementara, hidroksiapatit hasil dekomposisi termal $400^{\circ} \mathrm{C}$ termodifikasi $\mathrm{Fe}\left(\mathrm{TA}_{2}\right)$ dengan penambahan $\mathrm{H}_{2} \mathrm{O}_{2}$ 1,0\% mengikuti model isoterm adsorpsi tipe-C. Ini terjadi karena zat terlarut dalam adsorbat lebih mudah masuk ke dalam pori adsorben daripada berinteaksi dengan pelarut. Hidroksiapatit hasil dekomposisi termal $400^{\circ} \mathrm{C}$ $\left(\mathrm{TA}_{1}\right)$, hidroksiapatit hasil dekomposisi termal $400^{\circ} \mathrm{C}$ termodifikasi $\mathrm{Fe}\left(\mathrm{TA}_{2}\right)$, serbuk tulang $\left(\mathrm{T}_{0}\right)$ dengan penambahan $\mathrm{H}_{2} \mathrm{O}_{2} 2,0 \%$, hidroksiapatit hasil dekomposisi termal $400^{\circ} \mathrm{C}\left(\mathrm{TA}_{1}\right)$ dengan penambahan $\mathrm{H}_{2} \mathrm{O}_{2} \quad 0,5 ; 1,5$; dan $2,0 \%$, hidroksiapatit hasil dekomposisi termal $400^{\circ} \mathrm{C}$ termodifikasi $\mathrm{Fe}\left(\mathrm{TA}_{2}\right)$ dengan penambahan $\mathrm{H}_{2} \mathrm{O}_{2}$ 1,5 dan 2,0\% mengikuti model isoterm adsorpsi tipe-S. Model adsorpsi tipe-S biasanya terjadi jika adsorben mempunyai afinitas yang tinggi terhadap pelarut, dengan arah kurva menunjukkan bahwa adsorpsi lebih mudah terjadi pada kenaikan konsentrasi awal zat yang teradsorpsi (Khan, 1980).

\section{SIMPULAN DAN SARAN}

\section{Simpulan}

Berdasarkan hasil penelitian dapat disimpulkan bahwa situs aktif dan luas permukaan adsorben tertinggi dimiliki oleh hidroksiapatit hasil dekomposisi termal $400^{\circ} \mathrm{C}\left(\mathrm{TA}_{1}\right)$ secara berturutturut yaitu sebesar $19,3493 \times 10^{23}$ situs/gram dan $26,5375 \mathrm{~m}^{2} / \mathrm{g}$. Secara umum adsorpsi congo red dengan penambahan $\mathrm{H}_{2} \mathrm{O}_{2}$ memiliki peningkatan jumlah teradsorpsi seiring dengan bertambahnya konsentrasi congo red.

\section{Saran}

Perlu dilakukan penelitian lanjutan mengenai kemampuan adsorpsi hidroksiapatit terhadap limbah simulasi campuran maupun aplikasi pada limbah sebenarnya.

\section{UCAPAN TERIMA KASIH}

Penulis Penulis sampaikan ucapan terima kasih kepada Ketut Gede Dharma Putra, I Made Oka Adi Parwata, dan I Wayan Suarsa dan semua pihak yang telah membantu sehingga tulisan ini dapat terselesaikan.

\section{DAFTAR PUSTAKA}

Adel, A., El-Zahhar, N.S., and Awwad, 2015, Removal of Malachite Green Dye from Aqueous Solution Using Organically Modified Hydroxyapatite, Journal of Environmental Chemical Engineering, 4 : 633-638

JCPDSCard File No. 9-432 (Hydroxyapatite), 1996, Joint Comitte on Powder Diffractions Standarts. Swatmore, PA

Khan, S.U., 1980, Pesticides in The Soil Environment, Elsevier Scientific Publishing Company, New York

Ooi,C.Y., Hamdi, M., and Ramesh, S. 2007, Properties of Hydroxyapatite Produced By Annealing of Bovine Bone. Ceramics International, 33 : 1171-1177

Parahita, I. G. A. A., Simpen, IN., dan Suastuti, N.G.A.M.A., 2016, Ekstraksi dan Karakterisasi Hidroksiapatit dari Limbah Kerajinan Tulang Sapi Menggunakan Metode Alkali Hidrtermal dan Dekomposisi Termal, Jurnal Kimia, 10 (2) : 229-235

Park, J.H., Lee, D.W., Im, S.W., Lee, Y.H., Suh, D.J., Jun, K.W., and Lee, K.Y., 2012, Oxidative Coupling of Methane using Non-stoichiometric Lead Hydroxyapatite Catalyst Mixtures, Fuel, 94 : 433-439

Patnaik, P, 2002, Handbook of Inorganik Chemical, McGraw-Hill, New York

Permana, C. R. I., 2010, Adsorpsi-Desorpsi Ion Cr(III) Pada Arang Tulang Sapi Teraktivasi $\mathrm{NaOH}$ dan Tersalut $\mathrm{Fe}_{2} \mathrm{O}_{3}$, Skripsi, Universitas Udayana, Denpasar 